\title{
Correlation and Path Coefficient Analysis for Yield and Yield Related Traits of Upland Rice (Oryza sativa L.) Genotypes in Northwestern, Ethiopia
}

\section{Tewachew Atsedemariyam}

\author{
Ethiopian Institute of Agricultural Research P.O.Box, 2003, Addis Ababa, Ethiopia. Pawe \\ Agricultural Research center, P.O.Box, 25, Pawe, Ethiopia.
}

\begin{tabular}{|c|c|}
\hline ARTICLE INFO & ABSTRACT \\
\hline $\begin{array}{l}\text { Article No.: 092818140 } \\
\text { Type: Research } \\
\text { DOI:10.15580/GJPBCS.2018.3.092818140 } \\
\text { Submitted: 28/09/2018 } \\
\text { Accepted: 09/10/2018 } \\
\text { Published: 03/12/2018 } \\
\text { *Corresponding Author } \\
\text { Atsedemariyam Tewachew } \\
\text { E-mail: atsdemary21@ gmail.com } \\
\\
\text { Keywords: Correlation, Direct } \\
\text { effect, Indirect effect, Rice and Path } \\
\text { coefficient analysis. }\end{array}$ & $\begin{array}{l}\text { This research was conducted with the objective of assessing the trait } \\
\text { association and direct and indirect effects of yield related traits on grain } \\
\text { yield of upland rice genotypes. A total of } 23 \text { rice genotypes evaluated in } \\
\text { randomized complete block design with three replications in } 2017 \text { main } \\
\text { cropping season at Pawe and Assosa. Grain yield exhibits highly } \\
\text { significant ( } \mathrm{p} \leq .01 \text { ) positive genotypic correlation with days to maturity } \\
\text { (rg=0.61), kernel length ( } \mathrm{rg}=0.55) \text { and plant height (rg=0.59) at both } \\
\text { locations, grain yield showed significant positive phenotypic correlations } \\
\text { with plant height ( } \mathrm{rp}=0.44) \text { and thousand grain weight (rp=0.29). The } \\
\text { genotypic path coefficient analysis at Pawe revealed that days to } \\
\text { maturity, plant height and length width ratio exerted highest positive } \\
\text { direct effect on grain yield and at Assosa thousand grain weight and } \\
\text { panicle length exerted positive direct effect on grain yield at phenotypic } \\
\text { level. The existence of strong positive correlation between grain yield and } \\
\text { other traits helps in identifying traits that could be used for indirect } \\
\text { selection for the improvement of grain yield. Therefore, to facilitate } \\
\text { selection in breeding for high yield and other desirable traits, it is logical } \\
\text { to examine various components and give more attention to those having } \\
\text { the greatest influence on grain yield. }\end{array}$ \\
\hline
\end{tabular}

Article No.: 092818140

Type: Research

DOI:10.15580/GJPBCS.2018.3.092818140

Submitted: 28/09/2018

Accepted: 09/10/2018

Published: 03/12/2018

*Corresponding Author

Atsedemariyam Tewachew

E-mail: atsdemary21@gmail.com

Keywords: Correlation, Direct effect, Indirect effect, Rice and Path the greatest influence on grain yield. 


\section{INTRODUCTION}

Rice belongs to the family Poaceae and genus Oryza and most probably originated in India or Southeastern Asia. It is the world's second most important cereal crop next to wheat. It has two cultivated and 22 wild species. The cultivated species are the Asian rice, Oryza sativa L. and the African rice, Oryza glaberrima Steud. Rice is a diploid species with a chromosome number of $2 n=24$, is normally a self-pollinated crop but up to $3 \%$ natural out crossing may occur depending on the cultivar and the environment, although about $0.5 \%$ is the average out-crossing level (Poehlman and Sleper, 1995). The production of $d$ constraints are many of which the development of rice varieties with higher yield potential and greater yield stability are needed to tackle the food insecurity in many countries of the world (Dogara and Jumare, 2014).

Ethiopia has tremendous potential to Increase the area under rice and is looking for partnerships to make use of this land (ECRD, 2012). In Ethiopia, in 2017 , about $48,418.09$ ha of land were cultivated to with the total production of 1,360,007.26 Quintals (CSA, 2017). Path coefficient analysis partitions the genetic correlation between yield and its component traits into direct and indirect effects and hence has effectively been used in identifying useful traits as selection criteria to improve grain yield in rice (Sadeghi, 2011). The goal of the path analysis is to accept descriptions of the correlation between the traits, based on a model of cause and effect relationship and to estimate the importance of the affecting traits on a specific trait (Azarpor, 2013).

Correlation study provides a measure of association between characters and helps to identify important characters to be considered while making elucidates selection. Breeding strategy in rice mainly depends upon the degree of associated characters as well as its magnitude and nature of variation (Zahid et al., 2006). Therefore, this research was conducted with the objective to determine association among traits, direct and indirect effects of traits on grain yield of upland rice.

\section{MATERIALS AND METHODS}

The experiment was conducted at two locations, namely Pawe Agricultural Research Center (PARC) and Assosa during the main cropping season of 2017. A total of 23 upland rice genotypes were obtained from Fogera National Rice Research and Training Center (FNRRTC).The experiment was conducted in Randomized Complete Block Design (RCBD) with three replications. A plot consisting six rows of $5 \mathrm{~m}$ long by $1.2 \mathrm{~m}$ width $\left(6 \mathrm{~m}^{2}\right)$ with spacing of $0.2 \mathrm{~m}$ between rows, $0.3 \mathrm{~m}$ between plots and $1.5 \mathrm{~m}$ between blocks was used. Data on grain yield and other important agronomic traits and quality traits were collected on plot and individual plant basis at each location. Crop phenology parameters were registered by visual observation of plants grown in a net plot, growth characters were measured from pre-tagged 5 randomly taken plants from central rows while yield and yield components were measured from plants in the net plots.

\section{Data Analysis}

Phenotypic $\left(r_{p}\right)$ and genotypic $\left(r_{g}\right)$ correlations between two traits were estimated using the formula suggested by Johnson et al. (1955) and Singh and Chaudhury (1985).

$$
\mathrm{r}_{\mathrm{p}}=\frac{\mathrm{P} \operatorname{cov}_{\mathrm{xy}}}{\sqrt{\left(\mathrm{V}_{\mathrm{p}} \mathrm{x} \cdot \mathrm{V}_{\mathrm{p}} \mathrm{y}\right)}} \quad r_{g}=\frac{G \operatorname{cov}_{x y}}{\sqrt{\left(\mathrm{V}_{\mathrm{g}} x \cdot V_{g} y\right)}}
$$

Where,

$r_{p}=$ Phenotypic correlation coefficient

$r_{g}=$ Genotypic correlation coefficient

$P_{c o v}=$ Phenotypic covariance between variables $x$ and $y$

$\mathrm{Gcov}_{\mathrm{xy}}=$ Genotypic covariance between variables $\mathrm{x}$ and $y$

$V_{p} x=$ Phenotypic variance of variable $x$

$\mathrm{V}_{\mathrm{g}} \mathrm{x}=$ Genotypic variance of variable $\mathrm{x}$

$V_{p} y=$ Phenotypic variance of variable $y$

$\mathrm{V}_{\mathrm{g}} \mathrm{y}=$ Genotypic variance of variable $\mathrm{y}$ 
The calculated phenotypic correlation value was tested for its significance using t-test:

$\mathrm{t}=\mathrm{r}_{\mathrm{ph}} / \mathrm{SE}\left(\mathrm{r}_{\mathrm{p}}\right)$

Where, $r_{p}=$ Phenotypic correlation; $\operatorname{SE}\left(r_{p}\right)=$ Standard error of phenotypic correlation obtained using the following formula (Sharma, 1998).

SE $\left(r_{p}\right)=\sqrt{\frac{1-r^{2} p h}{n-2}}$

Where, $n$ is the number of genotypes tested, $r_{p}^{2}$ is phenotypic correlation coefficient.

The coefficients of correlations at genotypic levels were tested for their significance by the formula described by Robertson (1959) as indicated below:

$\mathrm{t}=\mathrm{r}_{\mathrm{gxy}} / \mathrm{SEr} \mathrm{r}_{\mathrm{gxy} 2}$

The calculated "t" value was compared with the tabulated "t" value at $(n-2)$ degree of freedom at $5 \%$ level of significance. Where, $n$ is number of genotypes.

$\mathrm{SEr}_{\mathrm{gxy}}=\sqrt{\frac{1-\mathrm{r} 2 \mathrm{gxy}}{\mathrm{h} 2 \mathrm{x}} \cdot \mathrm{h} 2 \mathrm{y}}$

Where, $h^{2} x=$ Heritability of trait $x . h^{2} y=$ Heritability of trait $y$.

Based on genotypic and phenotypic correlations, path coefficient analysis which refers to the estimation of direct and indirect effects of the seed yield attributing characters (independent character) on seed yield (dependent character) was calculated based on the method used by Dewey and Lu (1959) as follows:

rij $=$ Pij $+\sum$ rikpkj

where,

rij = mutual association between the independent character (i) and dependent character (j) as measured by the genotypic and phenotypic correlation coefficients.
$\mathrm{Pij}=$ direct effects of the independent character (i) on the dependent variable (j) as measured by the genotypic path coefficients, and

¿rikpkj $=$ Summation of components of indirect effects of a given independent character (i) on a given dependent character (j) via all other independent characters $(k)$.

The residual effect, which determines how best the causal factors account for the variability of the dependent factor yield, was computed using the formula;

$$
1=p^{2} R+\sum p \text { ijrij }
$$

Where, $p^{2} R$ is the residual effect.

p ij rij = the product of direct effect of any variable and its correlation coefficient with yield.

\section{RESULTS AND DISCUSSION}

\section{Correlation Coefficient Analysis}

Grain yield exhibits highly significant positive genotypic correlation with days to maturity $(\mathrm{rg}=0.61)$, kernel length $(r g=0.55)$ and plant height $(r g=0.59)$. Days to heading $(\mathrm{rg}=0.5)$, days to flowering $(\mathrm{rg}=0.41)$ and length width ratio $(\mathrm{rg}=0.49)$ also showed significant positive correlation with grain yield at Pawe. Similar findings were observed by Khare et al. (2014) and reported positive significant correlation between grain yield with days to flowering, days to maturity and plant height. Ekka et al. (2015) also reported grain yield had significant and positive correlation with days to flowering and plant height; Reddy and Suresh, (2013) also reported grain yield showed significant positive correlation with plant height. At Assosa, there was no any yield related trait associate positively and significantly with grain yield at genotypic level. Plant height, kernel width, protein content, thousand grain weight and kernel thickens had positive genotypic association with grain yield but not significant.

At Pawe, The strongest and highly significant genotypic association was observed between days to heading and days to flowering $(\mathrm{rg}=0.95)$ followed by length width ratio with kernel length $(r g=0.94)$, kernel 
width with kernel thickens $(\mathrm{rg}=0.84)$ and days to significant positive genotypic correlations with days to heading with days to maturity $(\mathrm{rg}=0.83)$. The genotypic flowering $(\mathrm{rg}=0.95)$, days to heading $(\mathrm{rg}=0.95)$, kernel correlation coefficient in most cases was higher than length ( $\mathrm{rg}=0.77$ ), number of unfilled grains per panicle their corresponding phenotypic correlation coefficients indicating the association is largely due to genetic cause. Bagati et al. (2016) and Kumar and Roy (2015) reported similar findings. Days to heading showed significant $(\mathrm{rg}=0.01)$ strong positive genotypic $(\mathrm{rg}=0.55)$ and length width ratio $(\mathrm{rg}=0.79)$. Osman et al. (2012) also reported days to maturity were positively and significantly correlated with days to $50 \%$ flowering. Kernel length and length width ratio also showed highly correlation with days to flowering $(\mathrm{rg}=0.98)$ (Table 1$)$. In significant positive genotypic correlation with days to the same time, days to maturity showed highly heading and days to flowering at Assosa. 


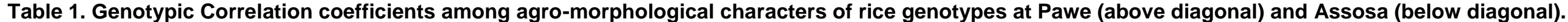

\begin{tabular}{|c|c|c|c|c|c|c|c|c|c|c|c|c|c|c|}
\hline Variable & $\mathrm{DH}$ & DF & $\mathrm{DM}$ & $\mathrm{PH}$ & PL & FTPP & UGPP & TGW & $\mathrm{KL}$ & $\mathrm{KW}$ & $\mathrm{KT}$ & L/W & $P C$ & GY \\
\hline $\mathrm{DH}$ & & $0.95^{\star *}$ & $0.83^{* *}$ & $0.83^{\star *}$ & 0.25 & 0.09 & 0.18 & $0.47^{*}$ & $0.59^{* *}$ & -0.32 & -0.46 & $0.56^{\star *}$ & -0.005 & $0.5^{*}$ \\
\hline DF & $0.98^{* *}$ & & $0.74^{* *}$ & $0.51^{*}$ & 0.31 & 0.05 & 0.09 & $0.45^{\star}$ & $0.53^{* *}$ & -0.22 & -0.4 & $0.47^{*}$ & -0.01 & $0.41^{*}$ \\
\hline DM & $0.95^{\star *}$ & $0.95^{\star *}$ & & $0.53^{* *}$ & 0.22 & 0.11 & 0.35 & 0.3 & $0.64^{* *}$ & -0.38 & -0.49 & $0.62^{* *}$ & -0.03 & $0.61^{* *}$ \\
\hline $\mathrm{PH}(\mathrm{cm})$ & -0.2 & -0.15 & -0.23 & & $0.66^{* *}$ & $0.42^{*}$ & 0.4 & 0.21 & 0.27 & 0.09 & -0.2 & 0.16 & 0.03 & $0.59^{* *}$ \\
\hline $\mathrm{PL}(\mathrm{cm})$ & 0.31 & 0.35 & 0.32 & $0.41^{*}$ & & 0.36 & -0.04 & 0.09 & 0.26 & 0.03 & -0.3 & 0.17 & 0.21 & 0.3 \\
\hline FTPP & 0.33 & $0.4^{*}$ & $0.44^{*}$ & -0.27 & -0.12 & & 0.24 & 0.06 & 0.3 & -0.4 & -0.41 & 0.39 & -0.34 & 0.33 \\
\hline UGPP & $0.46^{*}$ & 0.48 & $0.55^{\star *}$ & 0.03 & 0.13 & $0.41^{*}$ & & -0.2 & 0.03 & -0.29 & -0.26 & 0.14 & -0.01 & 0.23 \\
\hline TGW(g) & -0.04 & 0 & -0.1 & 0.16 & -0.12 & -11 & -0.31 & & $0.58^{* *}$ & 0.15 & 0.12 & 0.35 & 0.01 & 0.28 \\
\hline $\mathrm{KL}(\mathrm{mm})$ & $0.75^{\star \star}$ & $0.78^{\star \star}$ & $0.77^{\star *}$ & -0.33 & 0.24 & $0.54^{* *}$ & $0.42^{*}$ & 0.16 & & $-0.54^{\star \star}$ & -0.52 & $0.94^{\star *}$ & 0.11 & $0.55^{\star *}$ \\
\hline $\mathrm{KW}(\mathrm{mm})$ & $-0.6^{\star \star}$ & $-0.58^{\star \star}$ & $-0.64^{\star \star}$ & 0.3 & -0.18 & $-0.5^{*}$ & $-0.49^{*}$ & 0.42 & $-0.69^{\star *}$ & & $0.84^{* *}$ & $-0.80^{* *}$ & 0.78 & -0.24 \\
\hline $\mathrm{KT}(\mathrm{mm})$ & $-0.56^{\star *}$ & $-0.56^{\star *}$ & $-0.63^{\star *}$ & -0.09 & $-0.49^{\star *}$ & -0.21 & $-0.42^{*}$ & $0.41^{*}$ & $-0.48^{*}$ & $0.79^{* *}$ & & $-0.72^{\star *}$ & -0.05 & -0.35 \\
\hline $\mathrm{L} / \mathrm{W}(\mathrm{mm})$ & $0.76^{\star *}$ & $0.77^{\star *}$ & $0.79^{* *}$ & -0.35 & 0.24 & $0.56^{* *}$ & $0.5^{*}$ & $-0.07^{*}$ & $0.95^{\star *}$ & $-0.88^{* *}$ & $-0.65^{\star *}$ & & 0.04 & $0.49^{*}$ \\
\hline PC (\%) & 0.35 & 0.37 & 0.4 & -0.05 & 0.19 & 0.12 & 0.38 & 0 & 0.17 & -0.16 & -0.22 & 0.17 & & 0.16 \\
\hline GY(kg/h) & $-0.43^{*}$ & $-0.44^{*}$ & $-0.42^{*}$ & 0.24 & -0.12 & -0.26 & -0.3 & 0.02 & $-0.44^{*}$ & 0.27 & 0.08 & $-0.42^{*}$ & 0.02 & \\
\hline
\end{tabular}

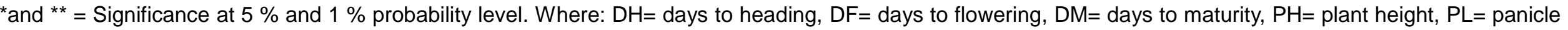

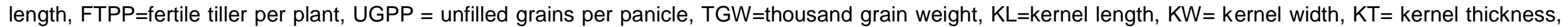
$\mathrm{L} / \mathrm{W}=$ length width ratio, $\mathrm{PC}=$ protein content and $\mathrm{GY}=$ grain yield 
At phenotypic level grain yield was highly significant and positively associated with plant height $(r p=0.57)$, panicle length $(r p=0.37)$, fertile tiller per plant $(r p=0.33)$, kernel length $(r p=0.51)$ and length width ratio $(r p=0.45)$ at Pawe. The study also indicated a positive and significant $(P \leq 0.05)$ phenotypic correlation for days to heading $(r p=0.27)$ and numbers of unfilled grains per plant ( $r p=0.28)$. Similar results also reported by Kumar and Ravindrababu (2016) for plant height, panicle length and fertile tiller per plant; Fiyaz et al. (2011) also reported highly significant and positively association of grain yield with plant height. At Assosa, grain yield showed highly significant and significant positive phenotypic correlations with plant height $(\mathrm{rp}=0.44)$ and thousand grain weight $(r p=0.29)$ respectively.

At Pawe, Plant height have highly significant and strong positive correlation with panicle length $(r p=0.69)$, fertile tiller per plant $(r p=0.41)$, unfilled grains per panicle $(r p=0.35)$ and significant positive correlation with kernel length $(r p=0.24)$ and thousand grain weight with a correlation coefficient of $r p=0.26$. Kumar and Ravindrababu (2016) also report plant height had significant and positive phenotypic correlation with panicle length. At Assosa, The strongest phenotypic association was observed between kernel length and length width ratio $(\mathrm{rp}=0.91)$ followed by days to maturity with days to heading $(r p=0.89)$. Highly significant positive association among yield attributes indicates that, the increase in one trait will cause increase in the associated trait, which in turn will cause an increase in grain yield.

Generally, the values of genotypic correlation coefficients were higher than the corresponding phenotypic correlation coefficients for most of the traits. This suggests that there was inherent relationship between these traits. The positive association between all possible pair of traits suggested that the possibility of correlated response to selection so that with the improvement of one trait, there will be an improvement in the other positively correlated trait. Unlike positive correlation, negative correlation between two desirable traits may impede or makes it impossible to achieve the simultaneous improvement of those traits along with each other. 


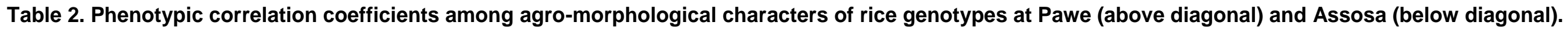

\begin{tabular}{|c|c|c|c|c|c|c|c|c|c|c|c|c|c|c|}
\hline Variable & $\mathrm{DH}$ & DF & $\mathrm{DM}$ & $\mathrm{PH}$ & PL & FTPP & UGPP & TGW & $\mathrm{KL}$ & $\mathrm{KW}$ & KT & $\mathrm{L} / \mathrm{W}$ & PC & GY \\
\hline $\mathrm{DH}$ & & $0.9^{* *}$ & $0.77^{* *}$ & 0.14 & 0.09 & 0.02 & 0.07 & 0.27 & $0.48^{* *}$ & $-0.28^{*}$ & $-0.37^{\star *}$ & $0.47^{* *}$ & 0.02 & $0.27^{*}$ \\
\hline DF & $0.95^{\star *}$ & & $0.69^{* *}$ & 0.08 & 0.12 & -0.03 & -0.03 & 0.21 & $0.38^{* *}$ & -0.2 & $-0.32^{\star *}$ & $0.36^{* *}$ & 0.04 & 0.17 \\
\hline DM & $0.89^{* *}$ & $0.87^{* *}$ & & 0.09 & 0.07 & -0.02 & 0.1 & 0.17 & $0.44^{* *}$ & $-0.28^{*}$ & $-0.34^{\star *}$ & $0.43^{* *}$ & 0.01 & 0.23 \\
\hline $\mathrm{PH}(\mathrm{cm})$ & -0.23 & -0.2 & -0.24 & & $0.69^{* *}$ & $0.41^{* *}$ & $0.35^{\star *}$ & $0.26^{*}$ & $0.24^{*}$ & 0.09 & -0.03 & 0.13 & 0.04 & $0.57^{\star *}$ \\
\hline $\mathrm{PL}(\mathrm{cm})$ & 0.22 & $0.27^{*}$ & $0.24^{*}$ & $0.37^{* *}$ & & $0.39^{* *}$ & 0.12 & 0.16 & $0.26^{*}$ & 0.06 & -0.16 & 0.17 & 0.15 & $0.37^{* *}$ \\
\hline FTPP & 0.21 & 0.19 & $0.32^{* *}$ & -0.03 & -0.13 & & $0.34^{* *}$ & 0.1 & $0.26^{*}$ & $-0.26^{*}$ & -0.22 & $0.31^{* *}$ & $-0.25^{\star}$ & $0.33^{* *}$ \\
\hline UGPP & $0.38^{* *}$ & $0.40^{* *}$ & $0.46^{\star *}$ & 0.11 & 0.06 & $0.32^{* *}$ & & -0.12 & 0.05 & -0.19 & -0.13 & 0.12 & -0.01 & $0.28^{*}$ \\
\hline TGW(g) & -0.09 & -0.09 & -0.2 & $0.35^{\star *}$ & -0.2 & 0.000 & -0.18 & & $0.46^{* *}$ & 0.14 & 0.05 & $0.27^{*}$ & 0.05 & 0.24 \\
\hline $\mathrm{KL}(\mathrm{mm})$ & $0.68^{* *}$ & $0.68^{* *}$ & $0.69^{* *}$ & -0.2 & 0.18 & $0.32^{* *}$ & $0.35^{* *}$ & 0.14 & & $-0.47^{* *}$ & $-0.39^{\star *}$ & $0.92^{* *}$ & 0.1 & $0.51^{* *}$ \\
\hline $\mathrm{KW}(\mathrm{mm})$ & $-0.5^{\star *}$ & $-0.46^{* *}$ & $-0.52^{\star *}$ & 0.1 & -0.13 & $-0.38^{*}$ & $-0.39^{* *}$ & $0.29^{*}$ & $-0.5^{\star *}$ & & $0.74^{* *}$ & $-0.77^{* *}$ & 0.03 & -0.17 \\
\hline $\mathrm{KT}(\mathrm{mm})$ & $-0.56^{* *}$ & $-0.43^{* *}$ & $-0.51^{\star *}$ & -0.19 & $-0.35^{\star *}$ & -0.16 & $-0.38^{* *}$ & $0.24^{*}$ & $-0.3^{*}$ & $0.74^{* *}$ & & $-0.61^{* *}$ & -0.07 & -0.19 \\
\hline $\mathrm{L} / \mathrm{W}(\mathrm{mm})$ & $0.71^{\star *}$ & $0.69^{* *}$ & $0.73^{\star *}$ & -0.18 & 0.19 & $0.39^{* *}$ & $0.43^{* *}$ & -0.05 & $0.91^{* *}$ & $-0.81^{* *}$ & $-0.56^{\star *}$ & & 0.05 & $0.45^{\star *}$ \\
\hline PC (\%) & $0.29^{*}$ & $0.32^{\star *}$ & $0.36^{\star *}$ & 0.01 & 0.16 & 0.06 & $0.34^{\star \star}$ & -0.01 & 0.14 & -0.15 & -0.19 & 0.16 & & 0.15 \\
\hline $\mathrm{GY}(\mathrm{kg} / \mathrm{h})$ & $-0.41^{* *}$ & $-0.39^{* *}$ & $-0.36^{\star *}$ & $0.44^{* *}$ & 0.01 & -0.11 & -0.17 & $0.29^{*}$ & $-0.27^{*}$ & 0.2 & 0.05 & $-0.3^{*}$ & 0.03 & \\
\hline
\end{tabular}

*and ${ }^{* *}$, significant and highly significant, respectively. Where: $\mathrm{DH}=$ days to heading, $\mathrm{DF}=$ days to flowering, $\mathrm{DM}=$ days to maturity, $\mathrm{PH}=$ plant height, $\mathrm{PL}=$ panicle length, FTPP=fertile tiller per plant, UGPP = unfilled grains per panicle, TGW=thousand grain weight, $\mathrm{KL}=\mathrm{kernel}$ length, $\mathrm{KW}=\mathrm{kernel}$ width, $\mathrm{KT}=\mathrm{kernel}$ thickens, $\mathrm{L} / \mathrm{W}=$ length width ratio, $\mathrm{PC}=$ protein content and $\mathrm{GY}=$ grain yield. 


\section{Path Coefficient Analysis}

The genotypic path coefficient analysis at Pawe revealed that days to maturity, plant height and length width ratio exerted highest positive direct effect on grain yield. Khare et al. (2014) also reported days to maturity and plant height exerted highest positive direct effect on grain yield. Length width ratio (9.548) had maximum positive direct effect on grain yield followed by plant height (0.961) and days to maturity (0.436) while kernel length had maximum negative direct effect on grain yield followed by days to heading and days to flowering. Days to heading, days to flowering and kernel length were positively correlated with grain yield but their direct effects were negative, indicating that indirect effects would be the cause of correlation. In this situation, the indirect causal factors were to be considered simultaneously for selection. Therefore, it would be better to consider the other traits that showed high indirect effect on grain yield. Abarshahr et al. (2011) also reported days to 50\% flowering had negative direct effect on grain yield.

At Pawe, the phenotypic path analysis revealed that length width ratio exerted the highest positive direct effect on grain yield followed by plant height, fertile tiller per plant and unfilled grains per panicle indicating that the selection for this character was likely to bring about an overall improvement in grain yield per plant directly. Kalyan et al. (2017) also reported Plant height had positive phenotypic direct effect on grain yield while the correlation of plant height with grain yield was positive and significant. At Assosa, Panicle length (0.45) had the highest positive direct effect at phenotypic level on grain yield. Days to heading, thousand grain weight, kernel thickens and length width ratio had maximum positive indirect effect through panicle length, however days to maturity, panicle length, unfilled grains per panicle, kernel length and kernel width had maximum negative indirect effect through this trait. Thousand grain weight had also the highest positive direct effect on grain yield.

Generally, path coefficient analysis is aimed to analyze and determine the traits having greater and true interrelationship with grain yield through partitioning of the correlation coefficient into direct and indirect effects. As a result of this, traits that exerted positive direct effect and positive and significant correlation with grain yield needs much attention in selection program. In addition to this, traits that showed considerable positive indirect effects via other traits should be considered simultaneously as indirect selection criteria for grain yield improvement. 
Table 3. Genotypic path analysis of the direct (bold) and indirect effects of yield related traits on grain yield of 23 rice genotypes at Pawe, 2017.

\begin{tabular}{|c|c|c|c|c|c|c|c|c|c|c|c|c|c|c|}
\hline Trait & $\mathrm{DH}$ & DF & DM & $\mathrm{PH}$ & $\mathrm{KL}$ & $L / W$ & $\mathrm{PL}$ & FTPP & UGPP & TGW $(\mathrm{g})$ & $\mathrm{KW}(\mathrm{mm})$ & $\mathrm{KT}(\mathrm{mm})$ & $\mathrm{PC}(\%)$ & $\mathrm{rg}$ \\
\hline $\mathrm{DH}$ & -0.353 & -0.075 & 0.363 & 0.509 & -3.945 & 5.34 & -0.121 & 0.009 & -0.063 & 0.031 & -1.141 & -0.051 & -0.002 & 0.502 \\
\hline DF & -0.335 & -0.078 & 0.325 & 0.495 & -3.516 & 4.506 & -0.151 & 0.004 & -0.032 & 0.03 & -0.786 & -0.045 & -0.004 & 0.412 \\
\hline DM & -0.294 & -0.058 & 0.436 & 0.508 & -4.246 & 5.896 & -0.105 & 0.01 & -0.127 & 0.02 & -1.366 & -0.055 & -0.01 & 0.608 \\
\hline $\mathrm{KL}(\mathrm{mm})$ & -0.209 & -0.042 & 0.279 & 0.261 & -6.647 & 8.928 & -0.123 & 0.028 & -0.012 & 0.038 & -1.935 & -0.058 & 0.038 & 0.547 \\
\hline $\mathrm{L} / \mathrm{W}(\mathrm{mm})$ & -0.197 & -0.037 & 0.269 & 0.152 & -6.215 & 9.548 & -0.084 & 0.035 & -0.052 & 0.023 & -2.882 & -0.08 & 0.014 & 0.495 \\
\hline
\end{tabular}

Table 4. Phenotypic path analysis of the direct (bold) and indirect effects of yield related traits on grain yield of 23 rice genotypes at Pawe, 2017.

\begin{tabular}{|c|c|c|c|c|c|c|c|c|c|c|c|c|c|c|}
\hline Trait & $\mathrm{DH}$ & $\mathrm{PH}(\mathrm{cm})$ & $\mathrm{PL}(\mathrm{cm})$ & FTPP & UGPP & $\mathrm{KL}(\mathrm{mm})$ & $\mathrm{L} / \mathrm{W}(\mathrm{mm})$ & DF & DM & TGW (g) & $\mathrm{KW}(\mathrm{mm})$ & $\mathrm{KT}(\mathrm{mm})$ & PC (\%) & $\mathrm{rp}$ \\
\hline $\mathrm{DH}$ & -0.049 & 0.074 & -0.017 & 0.002 & 0.002 & -1.233 & 1.993 & 0.001 & 0.036 & -0.028 & -0.525 & -0.001 & 0.003 & 0.259 \\
\hline $\mathrm{PH}(\mathrm{cm})$ & -0.007 & 0.534 & -0.131 & 0.034 & 0.020 & -0.601 & 0.563 & 0.000 & 0.004 & -0.026 & 0.175 & 0.000 & 0.006 & 0.570 \\
\hline $\mathrm{PL}(\mathrm{cm})$ & -0.004 & 0.369 & -0.190 & 0.032 & 0.007 & -0.665 & 0.700 & 0.000 & 0.003 & -0.016 & 0.115 & 0.000 & 0.024 & 0.374 \\
\hline FTPP & -0.001 & 0.219 & -0.075 & 0.082 & 0.019 & -0.654 & 1.288 & 0.000 & -0.001 & -0.010 & -0.497 & -0.001 & -0.040 & 0.330 \\
\hline UGPP & -0.003 & 0.187 & -0.023 & 0.028 & 0.057 & -0.120 & 0.498 & 0.000 & 0.004 & 0.012 & -0.362 & 0.000 & -0.002 & 0.276 \\
\hline $\mathrm{KL}(\mathrm{mm})$ & -0.024 & 0.126 & -0.050 & 0.021 & 0.003 & -2.545 & 3.884 & 0.000 & 0.020 & -0.047 & -0.892 & -0.001 & 0.016 & 0.512 \\
\hline $\mathrm{L} / \mathrm{W}(\mathrm{mm})$ & -0.023 & 0.071 & -0.032 & 0.025 & 0.007 & -2.346 & 4.214 & 0.000 & 0.020 & -0.028 & -1.469 & -0.002 & 0.008 & 0.446 \\
\hline
\end{tabular}

Table 5. Phenotypic path analysis of the direct (bold) and indirect effects of yield related traits on grain yield of 23 rice genotypes at Assosa, 2017.

\begin{tabular}{|c|c|c|c|c|c|c|c|c|c|c|c|c|c|c|}
\hline Trait & $\mathrm{PL}$ & TGW & $\mathrm{DH}$ & DF & DM & $\mathrm{PL}(\mathrm{cm})$ & FTPP & UGPP & $\mathrm{KL}(\mathrm{mm})$ & $\mathrm{KW}(\mathrm{mm})$ & $\mathrm{KT}(\mathrm{mm})$ & $\mathrm{L} / \mathrm{W}(\mathrm{mm})$ & $\mathrm{PC}(\%)$ & $\mathrm{rp}$ \\
\hline $\mathrm{PL}$ (cr & 0.45 & 0.02 & 0.1 & -0.001 & -0.1 & -0.06 & 0.003 & -0.01 & -1.21 & -0.4 & 0.02 & 1.63 & -0.0001 & 0.44 \\
\hline $\operatorname{TGW}(\mathrm{g})$ & 0.15 & 0.05 & 0.04 & 0 & -0.08 & 0.03 & 0.0002 & 0.02 & 0.85 & -1.18 & -0.02 & 0.43 & 0.0001 & 0.29 \\
\hline
\end{tabular}

Where: $\mathrm{DH}=$ days to heading, $\mathrm{DF}=$ days to flowering, $\mathrm{DM}=$ days to maturity, $\mathrm{PH}=$ plant height, $\mathrm{PL}=$ panicle length, $\mathrm{FTPP}=$ fertile tiller per plant, $\mathrm{UGPP}=$ unfilled grains per panicle, $T G W=$ thousand grain weight, $K L=k e r n e l$ length, $K W=$ kernel width, $K T=$ kernel thickens, $L / W=$ length width ratio and $P C=$ protein content. $\mathrm{rg}=$ genotypic correlation coefficient. 


\section{CONCLUSION}

In conclusion, Grain yield exhibits the highly significant positive genotypic correlation with days to maturity $(\mathrm{rg}=0.61)$, kernel length $(\mathrm{rg}=0.55)$ and plant height $(\mathrm{rg}=0.59)$ at Pawe. At Assosa, there was no any yield related trait associate positively and significantly with grain yield at genotypic level. Path analysis revealed that plant height, fertile tiller per plant, unfilled grains per panicle, length width ratio at Pawe and panicle length and thousand grain weight at Assosa are the most important characters which could be used as selection criteria for effective improvement on grain yield. Therefore, it is suggested that preference should be given to these characters in the selection programme to isolate superior lines with genetic potentiality for higher yield in rice genotypes. Hence, the information generated from this study, rice breeder can be exploited for future rice breeding program. The study was also carried out for one season and at two locations. However, further evaluation of these breeding materials at more locations and year is advisable to confirm the promising results observed in the present study.

\section{REFERENCES}

Abarshahr, M., Rabiei, B. and Lahigi, H.S. 2011. Genetic variability, correlation and path analysis in rice under optimum and stress irrigation regimes. Notulae Scientia Biologicae, 3(4): 134-142.

Azarpour E.2013. Path coefficient analysis for the yield components of rice cultivars in Iran under different nitrogen levels. Journal of biotechnology and environmental science, 3 (10): 24-30.

Bagati, S., Singh, A. K., Salgotra, R.K., Bhardwaj, R., Sharma, M., Rai, S.K., and Bhat, A., 2016. Genetic Variability Heritability and Correlation Coefficients of Yield and its Component Traits in Basmati Rice (Oryza sativa L.). SABRAO Journal of Breeding and Genetics, 48 (4): 445-452.

CSA (Central Statistical Agency).2017. Agricultura sample survey Report on area and Production of major crops. Central Statistical Agency of Ethiopia,
Addis Ababa, Ethiopia, Statistical Bulletin 584.

Dewey, D.R.and.Lu, H. 1959. A correlation and path coefficient analysis of components of crested wheat grass seed production. Agronomic Journal, 51: 515-518

Dogara, A.M. and Jumare, A.I., 2014. Origin, distribution and heading date in cultivated rice. International Journal of Plant Biology, 2(1): 1008.

Ekka, R.E., Sarawgi, A.K. and Kanwar, R.R. 2015. Genetic variability and inter-relationship analysis for various yield attributing and quality traits in traditional germplasm of rice (Oryza sativa L.). Plant Archives, 15(2): 637-645.

EUCORD (European Cooperative for Rural Development). 2012. Rice sector development in East Africa, a desk study prepared for the Common fund for commodities.

Fiyaz, A., Ramya, R., Chikkalingaiah, K.T., Ajay, B.C., Gireesh, C. and Kulkarni, R.S. 2011. Genetic variability, correlation and path co-efficient analysis studies in rice (Oryza sativa L.) under alkaline soil condition. Journal of plant breeding. 2 (4):531-537.

Johnson, H.W., Robinson, H.F. and Comstock, R. E. 1955. Estimates of genetic and environmental variability in soybeans 1 . Agronomy journal 47(7): 314-318.

Kalyan, B., Krishna, K. V. R., and Rao, L. V. S. 2017. Correlation Coefficient Analysis for Yield and its Components in Rice (Oryza sativa L.) Genotypes, 6(7): 2425-2430.

Khare, R., Singh, A.K., Eram, S. and Singh, P. K. 2015. Genetic variability, association and diversity analysis in upland Rice (Oryza sativa L). SAARC Journal of Agriculture,12(2), 40-51.

Kumar, R., and Roy, R. 2015. Genetic variability, correlation and path coefficient analysis for yield and yield components in transplant aman rice (OryzaSativa L.). BangldesheJournal of Botany, 44(4): 529-535.

Kumar, R.M., and Ravindrababu, V. 2016. Correlation between traits and path analysis co-efficient for grain yield and other components in direct seeded aerobic rice (Oryza sativa L.) Journal of crop improvement, 7(1):40-45.

Osman, K.A., Mustafa, A.M., Ali, F., Yonglain, Z. and 
Fazhan, Q. 2012. Genetic variability for yield and related attributes of upland rice genotypes in semi arid zone (Sudan).African Journal of Agricultural Research, 7(33): 4613-4619.

Poehlman, J.M., Sleper, D.A. and Rudd, J. 1995. Breeding field crops.(Vol.378).Ames: lowa State University Press.

Reddy, G. E., and Suresh, B. G. 2013. Correlation and path analysis for yield and yield attributes in rice (Oryza sativa L.) genotypes. International Journal of Plant Science.8(2): 391-394.

Sadeghi, S.M. 2011. Heritability, phenotypic correlation and path coefficient studies for some agronomic characters in landrace rice varieties. World Applied Science Journal, 13, 1229-1233.

Sharma, J.R.1998. Statistical and biometrical techniques in plant breeding. New Age International (P) limited, publishers. New Delhi. 432p.

Zahid, M.A., Akhter, M., Sabar, M., Manzoor, Z. and Awan, T. 2006. Correlation and path analysis studies of yield and economic traits in Basmati rice (Oryza sativa L.). Asian Journal of Plant Sciences, 5(4): 643-645.

Cite this Article: Tewachew, A (2018). Correlation and Path Coefficient Analysis for Yield and Yield Related Traits of Upland Rice (Oryza sativa L.) Genotypes in Northwestern, Ethiopia. Greener Journal of Plant Breeding and Crop Science, 6(3), 15-25, http://doi.org/10.15580/GJPBCS.2018.3.092818140. 